Article

\title{
Cinnamic Acid Inhibited Growth of Faba Bean and Promoted the Incidence of Fusarium Wilt
}

\author{
Qian Zhao, Ling Chen, Kun Dong, Yan Dong * and Jingxiu Xiao \\ College of Resources and Environment, Yunnan Agricultural University, Kunming 650201, China; \\ z07070419@163.com (Q.Z.); qzyauedu@163.com (L.C.); 2000028@ynau.edu.cn (K.D.); 2005023@ynau.edu.cn (J.X.) \\ * Correspondence: 2002030@ynau.edu.cn; Tel.: +86-136-4882-9768
}

Received: 7 August 2018; Accepted: 2 October 2018; Published: 11 October 2018

\begin{abstract}
To ascertain the role and mechanism of cinnamic acid in the process of soil-borne Fusarium wilt infection with fava bean, we studied the effect of cinnamic acid on the faba bean and Fusarium oxysporum f. fabae (FOF). Our results showed that cinnamic acid treatment affected the physiological resistance of faba bean to FOF after inoculation with the pathogen and enhanced the pathogenicity of the pathogen, which may have led to aggravation of infection by the pathogen and increases in the incidence rates of Fusarium wilt and disease.
\end{abstract}

Keywords: allelopathy; faba bean; Fusarium oxysporum f. fabae (FOF); pathogenicity; phenolic acid

\section{Introduction}

The faba bean (Vicia faba L.) is an important leguminous crop for multitudes worldwide. It is widely used as food, fodder, and green manure, and has high adaptability and high nitrogen fixation. In recent years, faba bean production has been under continuous development to improve its yield under various planting and environmental conditions. The faba bean tends to experience obstacles to replantation after continuous cropping, especially soil-borne diseases and low yield [1].

Fusarium wilt is among the main soil-borne diseases threatening the production of faba bean [2], as well as many other crops, including cucumber (Cucumis sativus L.), watermelon (Citrullus lanatus (Thunb.) Matsum. et Naka), and strawberry (Fragaria ananassa Duch.) [3-5]. This disease is principally caused by Fusarium oxysporum [6], which infects plants by interfering with signal recognition in host plants and destroying plant defence systems.

Many researchers have found that allelopathy and autotoxicity are closely related to problems in continuous cropping, with connections made to numerous allelochemicals. Phenolic acid is the most widely studied and active of these allelochemicals [7]. Researchers have isolated more than 10 types of phenolic acid from root exudates and decomposed residue of crops, such as watermelon, eggplant (Solanum melongena L.), lily (Lilium brownii var. viridulum Baker), and radix rehmanniae (Rehmannia glutinosa (Gaetn.) Libosch. ex Fisch. et Mey.) [8-11]. Among these, cinnamic acid is one of the most important phenolic acids [12]. Asaduzzaman and Asao [13] found that the addition of activated charcoal to hydroponic culture improved the growth of faba bean and the detection of several phenolic acids, including cinnamic acid, and that its self-toxic substances had an important inhibitory effect on plant growth.

Studies have shown that phenolic acids have a stimulating effect (positive or negative) on soil-borne pathogens. One study showed that $p$-hydroxybenzoic acid, vanillic acid, and ferulic acid, which are root exudates of cucumber, stimulated mycelial growth in F. oxysporum [14], and the experimental results of Wang et al. [15] showed that cinnamic acid inhibited the spore germination of Verticillium dahliae in eggplants. The stimulating effect of phenolic acids on pathogenic fungi has been linked to its concentrations in several studies. For example, in American ginseng 
(Panax quinquefolius L.), phenolic acid promoted Fusarium solani growth at concentrations of 0.5 and $0.75 \mathrm{mmol} \cdot \mathrm{L}^{-1}$, whereas $1 \mathrm{mmol} \cdot \mathrm{L}^{-1}$ inhibited growth [16].

In our early research, we detected seven phenolic acids in rhizosphere soil that continuous cropped faba bean, with cinnamic acid being the most abundant component [17]. However, the role of cinnamic acid, which constitutes the highest proportion of phenolic acid from faba bean root exudates, has not been reported in the process of soil-borne fusarium wilt infection, nor its mechanism.

Therefore, the objective of the current study was to examine the effects of cinnamic acid on the growth of faba bean seedlings. The effects of cinnamic acid on Fusarium wilt, antioxidant enzymes, and disease-related proteins in faba bean were studied using cinnamic acid treatments and inoculation of the pathogen. The mechanism of Fusarium wilt promotion by cinnamic acid in faba bean was explored from the perspective of the host and pathogen, to evaluate the effect of cinnamic acid on Fusarium oxysporum f. fabae (FOF) pathogenicity.

\section{Results}

\subsection{Effect of Cinnamic Acid on Plant Growth}

Growth parameters of faba bean all significantly decreased following cinnamic acid treatment, except for main root length and root-shoot ratio (Table 1). Cinnamic acid treatment significantly reduced the number of leaves per plant, by $24.64 \%, 40.01 \%$, and $45.41 \%$ at cinnamic acid concentrations of 50,100, and $200 \mathrm{mg} \cdot \mathrm{L}^{-1}$, respectively, compared with the control. Maximum leaf length declined by $20.28 \%, 24.15 \%$, and $47.25 \%$; maximum leaf width by $23.94 \%, 30.57 \%$, and $46.04 \%$, height by $15.29 \%$, $30.33 \%$, and $41.80 \%$; shoot dry weight by $25.56 \%, 58.74 \%$, and $68.16 \%$; and root dry weight by $27.28 \%$, $62.96 \%$, and $74.07 \%$, respectively (Table 1 ).

Table 1. Effects of cinnamic acid on the growth of faba bean seedlings after being inoculated with Fusarium oxysporum $\mathrm{f}$. fabae (FOF). Data are average values, with bars representing standard errors of three replicates. Different letters for each index indicate significant differences at a level of $p<0.05$, according to Duncan's test. There are no significant differences among values labeled "ab", "a", and " $\mathrm{b}$ ".

\begin{tabular}{ccccc}
\hline Growth Parameter & $\mathbf{0 ~} \mathbf{~} \mathbf{g} \cdot \mathbf{L}^{-\mathbf{1}}$ & $\mathbf{5 0} \mathbf{~} \mathbf{g} \cdot \mathbf{L}^{-\mathbf{1}}$ & $\mathbf{1 0 0} \mathbf{~} \mathbf{g} \cdot \mathbf{L}^{\mathbf{- 1}}$ & $\mathbf{2 0 0} \mathbf{~} \mathbf{g} \cdot \mathbf{L}^{\mathbf{- 1}}$ \\
\hline Leaf number per plant & $21.67 \pm 0.58 \mathrm{a}$ & $16.33 \pm 2.89 \mathrm{~b}$ & $13.00 \pm 1.00 \mathrm{c}$ & $11.83 \pm 0.29 \mathrm{~d}$ \\
Max leaf length (cm) & $8.73 \pm 0.38 \mathrm{a}$ & $6.80 \pm 0.61 \mathrm{~b}$ & $6.47 \pm 0.38 \mathrm{~b}$ & $4.50 \pm 0.10 \mathrm{c}$ \\
Max leaf width (cm) & $5.43 \pm 0.51 \mathrm{a}$ & $4.13 \pm 0.12 \mathrm{~b}$ & $3.77 \pm 0.55 \mathrm{~b}$ & $2.93 \pm 0.15 \mathrm{c}$ \\
Height $(\mathrm{cm})$ & $39.23 \pm 0.49 \mathrm{a}$ & $33.23 \pm 1.48 \mathrm{~b}$ & $27.33 \pm 1.11 \mathrm{c}$ & $22.83 \pm 0.58 \mathrm{~d}$ \\
Main root length $(\mathrm{cm})$ & $18.33 \pm 1.46 \mathrm{a}$ & $17.53 \pm 0.42 \mathrm{a}$ & $16.77 \pm 0.45 \mathrm{~b}$ & $13.23 \pm 0.31 \mathrm{c}$ \\
Shoot dry weight $(\mathrm{g})$ & $2.23 \pm 0.05 \mathrm{a}$ & $1.66 \pm 0.11 \mathrm{~b}$ & $0.92 \pm 0.21 \mathrm{c}$ & $0.71 \pm 0.08 \mathrm{c}$ \\
Root dry weight $(\mathrm{g})$ & $0.54 \pm 0.03 \mathrm{a}$ & $0.39 \pm 0.05 \mathrm{~b}$ & $0.20 \pm 0.05 \mathrm{c}$ & $0.14 \pm 0.04 \mathrm{c}$ \\
Root-shoot ratio (\%) & $0.24 \pm 0.02 \mathrm{a}$ & $0.23 \pm 0.02 \mathrm{a}$ & $0.22 \pm 0.01 \mathrm{ab}$ & $0.20 \pm 0.02 \mathrm{~b}$ \\
\hline
\end{tabular}

\subsection{Effect of Cinnamic Acid on Fusarium Wilt Incidence and Disease Indices}

The incidence of Fusarium wilt increased significantly under cinnamic acid stress at concentrations of 50, 100, and $200 \mathrm{mg} \cdot \mathrm{L}^{-1}$, and also increased as cinnamic acid content increased (Figure 1). Compared with the control, Fusarium wilt incidence increased by $21.67 \%, 46.5 \%$, and $50 \%$ with treatments of 50,100 , and $200 \mathrm{mg} \cdot \mathrm{L}^{-1}$, respectively, and the disease index significantly increased by $37.5 \%, 200 \%$, and $350.62 \%$ at treatment concentrations of 50,100, and $200 \mathrm{mg} \cdot \mathrm{L}^{-1}$ (Figure 1 ). In general, cinnamic acid led to increased Fusarium wilt incidence, and stimulated the conditions of the disease and its effects in a concentration-dependent manner. 


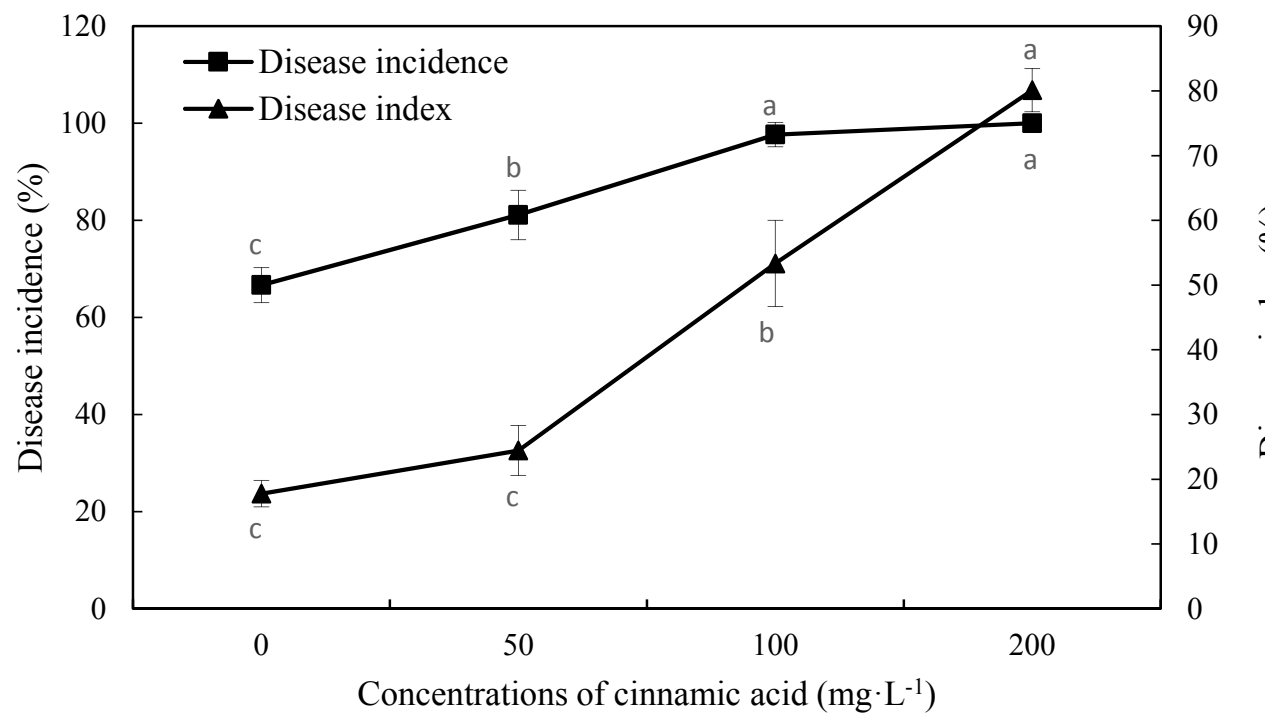

Figure 1. Effects of cinnamic acid on the incidence and index of faba bean Fusarium wilt. Data are average values, with bars representing standard errors of three replicates. Different letters for each index indicate significant differences at $p<0.05$, according to Duncan's test. There are no significant differences among values labeled " $a b$ ", " $a$ ", and " $b$ ".

\subsection{Effect of Cinnamic Acid on Seedling Root Physiological Activity}

Peroxidase (POD) and catalase (CAT) activities exhibited a significant negative relationship with cinnamic acid treatment concentration, decreasing in an almost linear manner as treatment concentration increased (Table 2). POD activity was inhibited by $17.14 \%, 30 \%$, and $48.57 \%$ at cinnamic acid concentrations of 50,100 , and $200 \mathrm{mg} \cdot \mathrm{L}^{-1}$, respectively, and CAT activity was reduced by $15.63 \%$, $44.77 \%$, and $62.97 \%$ (Table 2 ).

Table 2. Effect of cinnamic acid on seedling root physiological activity and content of malondialdehyde (MDA) after being inoculated with FOF. Data are average values, with bars representing standard errors of three replicates. Different letters for each index indicate significant differences at $p<0.05$, according to Duncan's test. There is no significant difference among values labeled "ab", " $a$ ", and " $b$ ".

\begin{tabular}{cccc}
\hline Concentration $\left.\mathbf{( m g} \cdot \mathbf{L}^{-\mathbf{1}}\right)$ & POD Activity $\left(\boldsymbol{\mu} \cdot \mathbf{g}^{-\mathbf{1}} \cdot \mathbf{m i n}^{-\mathbf{1}}\right)$ & CAT Activity $\left.\mathbf{( m g} \cdot \mathbf{g}^{-\mathbf{1}} \cdot \mathbf{m i n}^{-\mathbf{1}}\right)$ & MDA Content $\left(\boldsymbol{\mu} \mathbf{m o l} \cdot \mathbf{g}^{-\mathbf{1}}\right)$ \\
\hline 0 & $23.33 \pm 0.58 \mathrm{a}$ & $0.51 \pm 0.02 \mathrm{a}$ & $12.77 \pm 1.54 \mathrm{~d}$ \\
50 & $19.33 \pm 0.58 \mathrm{~b}$ & $0.43 \pm 0.04 \mathrm{~b}$ & $15.89 \pm 0.92 \mathrm{c}$ \\
100 & $16.33 \pm 1.53 \mathrm{c}$ & $0.28 \pm 0.02 \mathrm{c}$ & $17.94 \pm 0.90 \mathrm{~b}$ \\
200 & $12 \pm 1.73 \mathrm{~d}$ & $0.19 \pm 0.03 \mathrm{~d}$ & $21.04 \pm 0.47 \mathrm{a}$ \\
\hline
\end{tabular}

Malondialdehyde (MDA) content increased in faba bean seedling roots under cinnamic acid stress at almost all concentrations (Table 2) in a concentration-dependent manner.

\subsection{Effect of Cinnamic Acid on Pathogenesis-Related Faba Bean Seedling Root Proteins}

Seedling root $\beta-1,3$-glucanase activity showed a decreasing trend as cinnamic acid concentration increased, except at $50 \mathrm{mg} \cdot \mathrm{L}^{-1}$ where it showed a slight stimulating effect. With 100 and $200 \mathrm{mg} \cdot \mathrm{L}^{-1}$ treatments of cinnamic acid, $\beta-1,3$-glucanase activity decreased by $19.31 \%$ and $35.07 \%$, respectively, compared with the control (Figure 2). The chitinase activity trend was similar to that of $\beta$-1,3-glucanase activity, and compared with the control, had significant decreases at 100 and $200 \mathrm{mg} \cdot \mathrm{L}^{-1}$ by $28.84 \%$ and $48.94 \%$, respectively (Figure 3 ). 


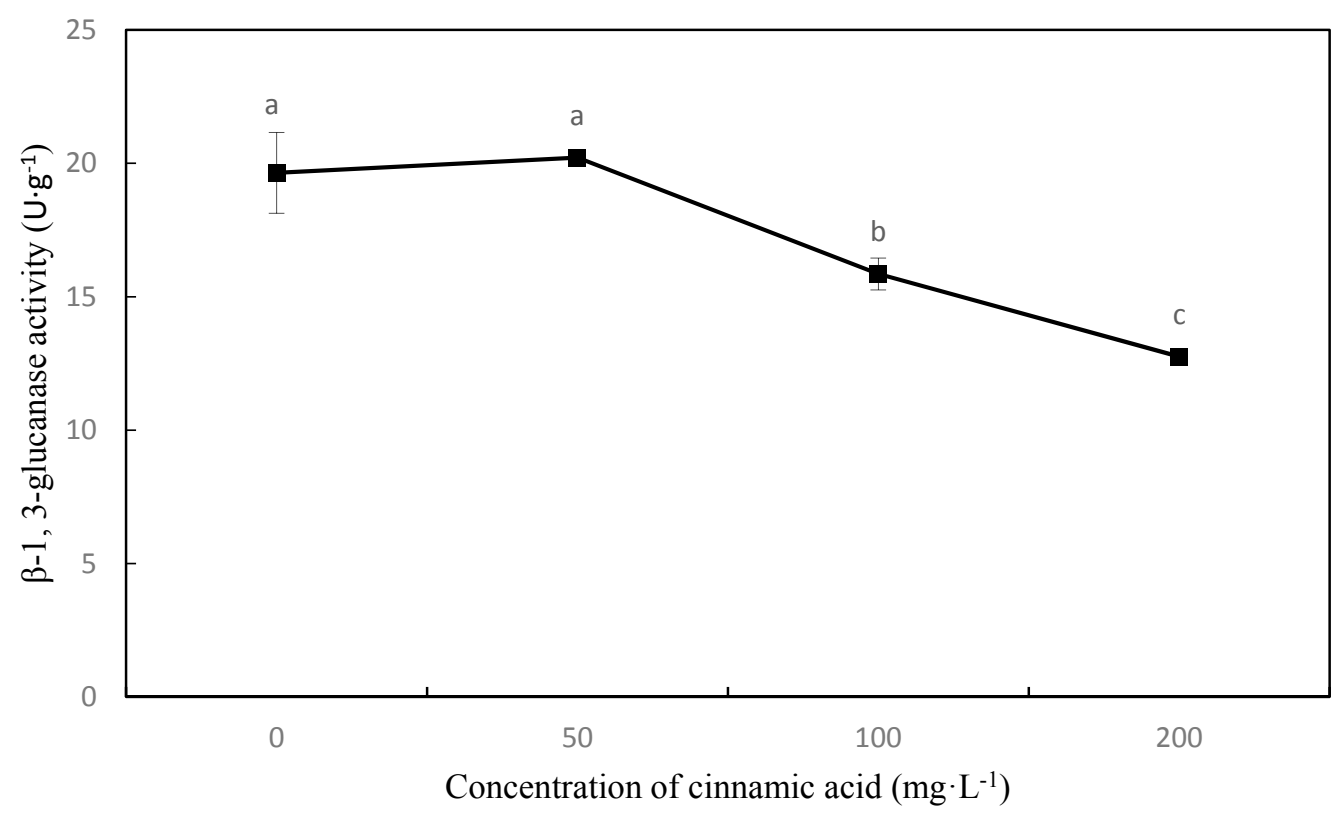

Figure 2. Effects of cinnamic acid on $\beta$-1, 3-glucanase activity in faba bean roots after being inoculated with FOF. Data are average values, with bars representing standard errors of three replicates. Different letters for each index indicate significant differences at $p<0.05$, according to Duncan's test. There are no significant differences among values labeled " $a b$ ", " $a$ ", and " $b$ "'.

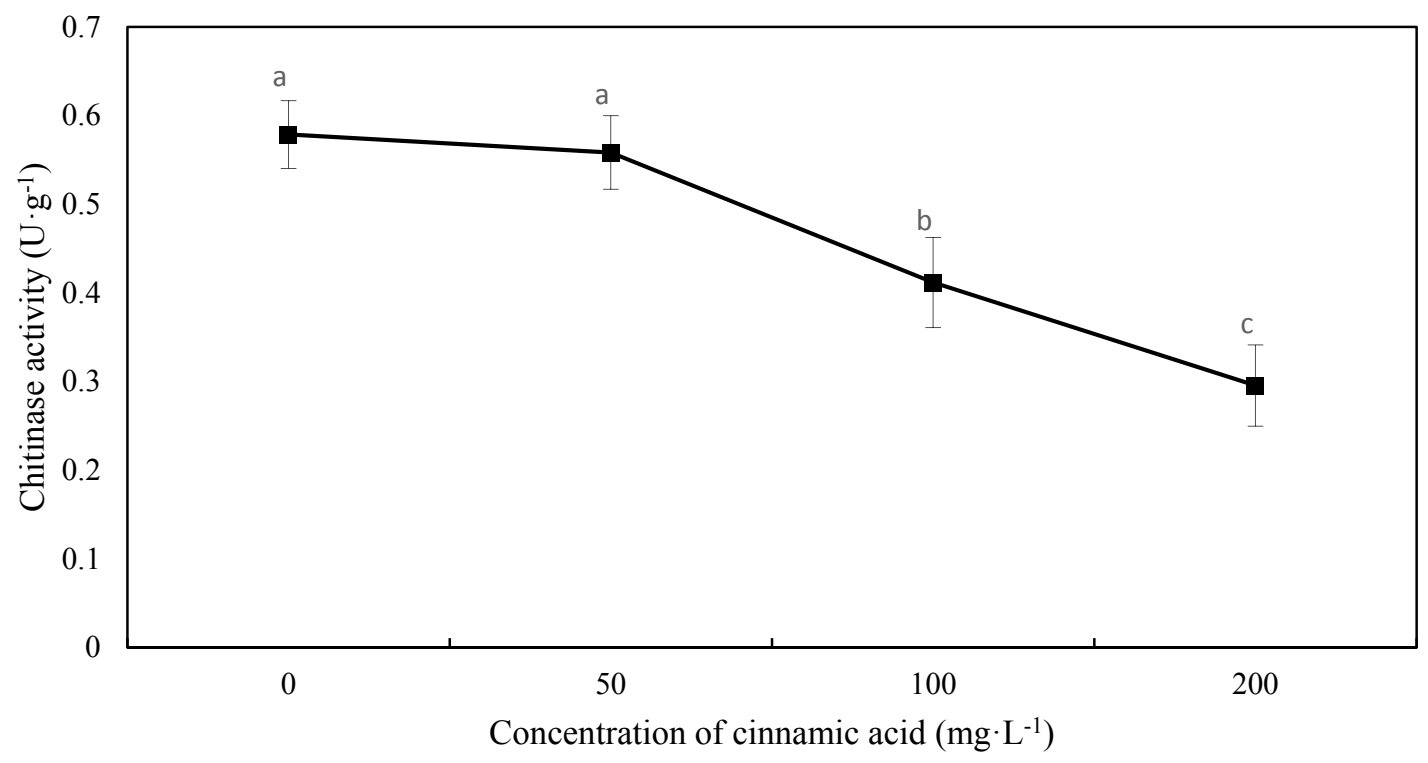

Figure 3. Effects of cinnamic acid on chitinase activity in faba bean roots after being inoculated with FOF. Data are average values, with bars representing standard errors of three replicates. Different letters for each index indicate significant differences at $p<0.05$, according to Duncan's test. There are no significant differences among values labeled " $a b$ ", “a", and " $b$ "'.

\subsection{Effect of Cinnamic Acid on FOF Mycotoxin Production}

FOF mycotoxin yield (FA) increased as cinnamic acid concentration increased, with a significant increase at $50 \mathrm{mg} \cdot \mathrm{L}^{-1}$ (Figure 4). FA yield increased by $166.32 \%, 236.58 \%$, and $247.12 \%$, respectively, at concentrations of 50, 100, and $200 \mathrm{mg} \cdot \mathrm{L}^{-1}$, compared with the control (Figure 4). 


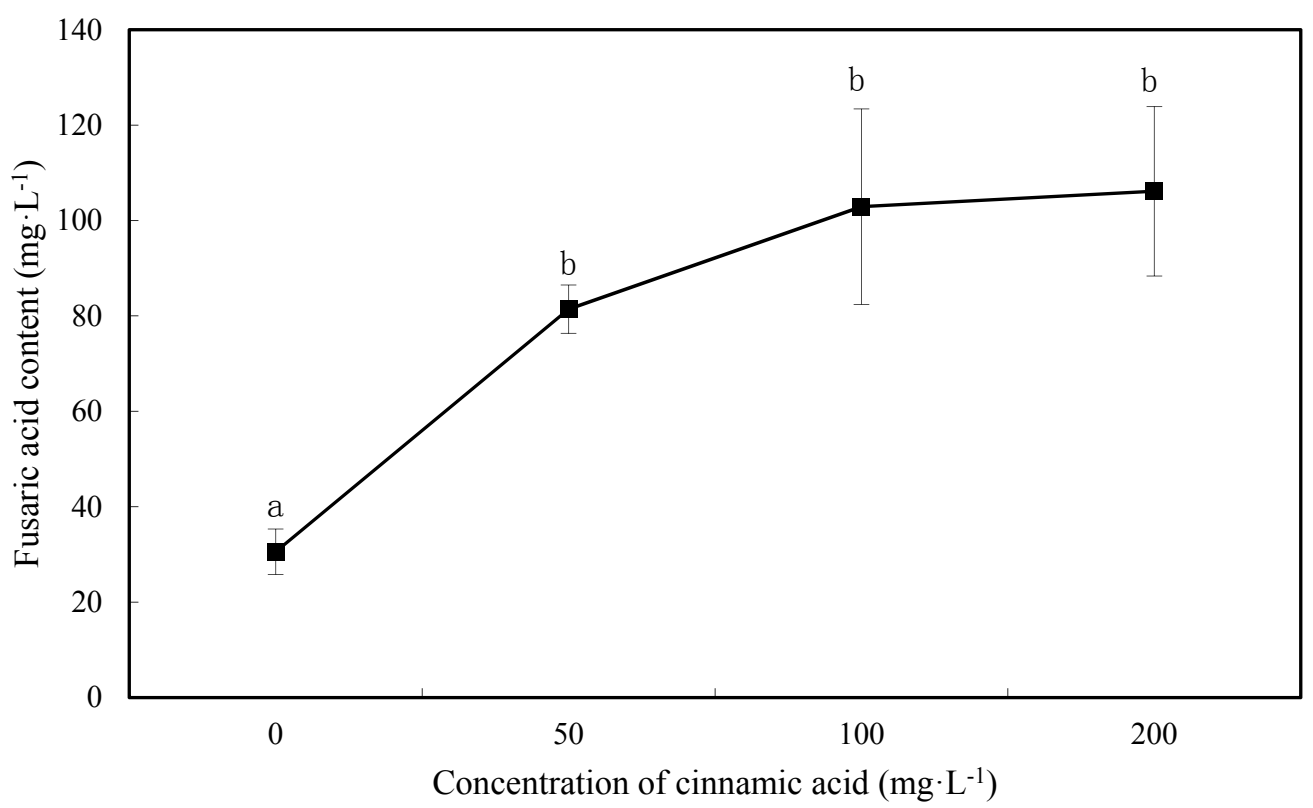

Figure 4. Effects of cinnamic acids at various concentrations on mycotoxin production of FOF. Data are average values, with bars representing standard errors of three replicates. Different letters for each index indicate significant differences at $p<0.05$, according to Duncan's test. Significant differences are labelled "a", "ab", and "b".

\subsection{Effect of Cinnamic Acid on the Activities of Hydrolytic Enzymes Related to Pathogenesis}

A slight increase in pectinase activity was observed under cinnamic acid stress, with increases of $18.67 \%, 21.96 \%$, and $17.15 \%$, respectively (Figure 5). Cellulase activity increased, then remained stable at $50-100 \mathrm{mg} \cdot \mathrm{L}^{-1}$ cinnamic acid, and then accelerated as the treatment concentration increased. With increasing concentrations of cinnamic acid, cellulase activity increased by $52.77 \%, 58.19 \%$, and $96.08 \%$, at 50, 100, and $200 \mathrm{mg} \cdot \mathrm{L}^{-1}$, respectively (Figure 5).

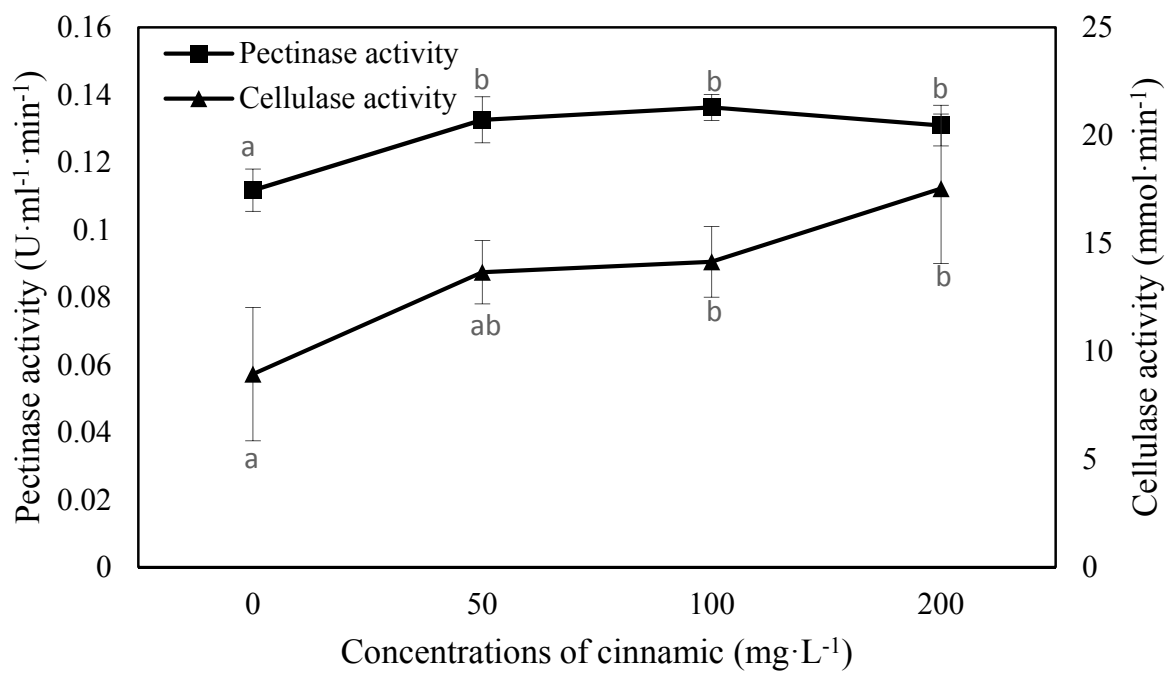

Figure 5. Effects of cinnamic acid at various concentrations on pectinase and cellulase activity of FOF. Data are average values, with bars representing standard errors of three replicates. Different letters for each index indicate significant differences at $p<0.05$, according to Duncan's test. Significant differences are labelled "a", " $a b$ ", and " $b$ ". 


\section{Discussion}

The role of phenolic acids has become a research hot spot in the field of autotoxicity. A study by Hu et al. [14] reported that exogenous application of $p$-hydroxybenzoic acid, vanillic acid, and ferulic acid slightly reduced plant height, root, stem, and leaf dry weight in cucumber seedlings, and induced seedling stem diameter narrowing and root length shortening. Other studies have shown that phenolic acids can have a hormetic effect on the seed germination or growth of plants [18,19], which is consistent with our results. In the current study, faba bean seedling growth was significantly inhibited under cinnamic acid and FOF stress, demonstrated by reduction of the number of leaves per plant, plant height, shoot dry weight, and root dry weight. This inhibitory effect increased as treatment concentration increased, and reached a significant level at $50 \mathrm{mg} \cdot \mathrm{L}^{-1}$ cinnamic acid (Table 1). This result indicates that cinnamic acid plays a role in inhibiting the growth of faba bean seedlings infected with FOF in a concentration-dependent manner.

Self-toxic substances also have an effect on the occurrence of soil-borne diseases, which can inhibit crop growth and reduce economic efficiency. In a study of continuous cropping in strawberries, ferulic and coumaric acids were detected. Continuous cropping soil was found to significantly promote strawberry anthracnose crown rot [20]; Qi et al. [21] reported that strawberry root tissues were significantly damaged under stress by p-hydroxybenzoic acid and Fusarium oxysporum, promoting the occurrence of strawberry blight. In the current study, the incidence of F. oxysporum in faba bean at the three treatment concentrations reached $81.11,97.67$, and $100 \%$, respectively, being $21.67 \%, 46.5 \%$, and $50 \%$ higher than that of the control. The disease index also increased significantly, by 200 and $350.62 \%$ at 100 and $200 \mathrm{mg} \cdot \mathrm{L}^{-1}$, respectively. These results are similar to those of Wang [22] who detected a significant increase in the incidence of fusarium wilt on watermelon seedlings; the disease index and seedling death rate increased as benzoic and cinnamic acid concentrations increased.

As the length of continuous cropping increases, autotoxic compounds accumulate in the soil. When these toxic substances reach a critical amount, the plant's physiological resistance will change, inducing a decline in resistance and tissue damage. Superoxide dismutase (SOD), POD, and CAT activities have been shown to increase in chili (Capsicum annuum L.) leaves planted in continuous cropping soil, and content of MDA and osmotic substances increased concurrently [23]. However, a study on Solanum melongena indicated that after years of continuous cropping, a large number of allelochemicals, including vanillin, had accumulated in the soil, leading to a decrease in root activity and chlorophyll content in tomato leaves at a $4.0 \mathrm{mmol} \cdot \mathrm{L}^{-1}$ concentration of vanillin; this was because the content of MDA and free proline (Pro) increased, and the relative permeability of the cell membrane increased [24]. Studies on strawberry, apple (Malus pumila Mill.), cucumber, and American ginseng showed that phenolic acid treatment reduced protective enzyme activities and increased cell membrane permeability [25-28]. These results are consistent with those of the current study, which showed that cinnamic acid treatment significantly reduced POD and CAT activity in faba bean roots and significantly increased MDA content, indicating that cinnamic acid and FOF stress reduced the activities of protective enzymes and stimulated lipid peroxidation in roots, weakening the physiological resistance of faba bean and promoting pathogen infection. These combined factors increased the rate of occurrence of Fusarium wilt in this species.

When host plants are infected by pathogenic bacteria, their defence response is initiated and the expression of disease-related proteins is induced, producing important hydrolases (e.g., chitinase and $\beta-1,3-$ glucanase) that hydrolyse the fungal cell wall, inhibiting fungal growth [29]. In soybean (Glycine max (Linn.) Merr.), resistance to Phytophthora sojae was positively correlated with $\beta$-1,3-glucanase and chitinase activity [30]. Other studies have shown that self-toxic substances are promoted under peroxidation stress and have an impact on the plant defence system. Appropriate concentrations of $\mathrm{p}$-hydroxybenzoic acid have been shown to enhance the induction of chitinase and $\beta$-1,3-glucanase activity, improving the resistance of Chinese cabbage (Brassica campestris L. ssp. chinensis var. utilis Tsen et Lee) to anthracnose [31]. Other studies have demonstrated that phenolic acids have a negative effect on chitinase and $\beta$-1,3-glucanase activity. Exogenous application of 
ferulic acid and inoculation with $F$. oxysporum have been shown to significantly inhibit chitinase activity in watermelon roots in a concentration-dependent manner, and has the greatest effect with the application of $100 \mu \mathrm{mol} \cdot \mathrm{L}^{-1}$ ferulic acid, leading to reductions of $62.5 \%$ in chitinase activity and $32.0-37.0 \%$ in $\beta-1,3$-glucanase activity in watermelon leaves [32]. In the current study, chitinase and $\beta$-1,3-glucanase activities were significantly lower than those of the control when cinnamic acid was applied at a concentration exceeding $50 \mathrm{mg} \cdot \mathrm{L}^{-1}$, indicating that cinnamic acid destroyed the defence system against FOF, thereby decreasing faba bean resistance against pathogenic bacteria and resulting in serious wilt disease.

Several allelochemicals can cause problems in continuous cropping. Of these, phenolic acids are the most studied, as well as the most active [33,34]; they have been shown to act as allelochemicals in root exudates [35-37], inhibit crop growth, and stimulate pathogens. The amount of F. oxysporum in the matrix increased by $76.7 \%$ and $104.6 \%$ when strawberry was treated with 0.2 and $0.4 \mathrm{mmol} \cdot \mathrm{L}^{-1}$ p-hydroxybenzoic acid, respectively [38]. Ferulic acid, a watermelon root exudate, significantly promoted F. oxysporum f. Sp. spore germination and sporulation, with promotion rates of $28.6-114.3 \%$ and $17.7-54.8 \%$, respectively, at concentrations of $40-160 \mathrm{mg} \cdot \mathrm{L}^{-1}$ [37]. During the infection process, the hydrolysis of enzymes (pectinase and cellulase) and pathogenic toxins is an important virulence factor that promotes the development of many plant fungal diseases and degrades cell wall tissues. Cell wall hydrolases promote host invasion by pathogen mycelia; the pathogen then secretes toxins, interferes with host metabolic functions, and destroys the plasma membrane, mitochondria, and chloroplasts [39-41]. In turn, membrane permeability is changed, affecting photosynthesis and respiration [42,43], inhibiting DNA, RNA, and other substances, as well as protein biosynthesis [44,45]. Studies have shown that the pathogenicity is closely related to enzyme and toxin production [46,47]. The results of the current study show that exogenous application of cinnamic acid promoted the production of $F$. oxysporum and hydrolytic enzymes at almost all concentrations. Thus, cinnamic acid promotes FOF infectivity and pathogenicity during infection.

However, these approaches, such as the application of bio-organic fertilizers, intercropping, mixed cropping, and rotation, can alleviate the effect of replanting obstacles and inhibit the occurrence of soil-borne diseases. Studies have shown that intercropping systems enrich the soil's microbial community structure, accelerate degradation of autotoxins such as cinnamic acid, reduce the self-toxic effect, and improve the physiological resistance of plants by resisting infection by pathogens and increasing crop yield [48-50].

\section{Materials and Methods}

\subsection{Test Materials}

The faba bean variety (Vicia faba L.), 89-147, used in this study was purchased from the Yunnan Academy of Agricultural Sciences (Yunnan Sheng, China). Analytical-grade cinnamic acid was purchased from China Pharmaceutical Group Shanghai Medical Instrument Co., Ltd. (Shanghai, China).

FOF was isolated from monocropped faba bean fields by the Plant-Microbe Laboratory at Yunnan Agricultural University, China. The fungus was transferred to potato dextrose agar (PDA) medium and incubated at $28^{\circ} \mathrm{C}$ in a temperature-controlled chamber for 7 days, and then stored in a refrigerator. The pectin, cellulose, and galacturonic acid used in this study were purchased from Tokyo Chemical Industry (Tokyo, Japan), Sigma Co. (St. Louis, MO, USA), and Ryon Co. (Shanghai, China), respectively.

\subsection{Preparation of Spore Suspension}

Spore suspensions of plant pathogens were obtained from 14-day-old cultures that were collected by adding $10 \mathrm{~mL}$ of sterile water to each Petri dish and rubbing the surface with a sterile L-shaped spreader. The suspension was filtered through four layers of cheesecloth. 


\subsection{Greenhouse Experiments}

Faba bean seeds were soaked for $24 \mathrm{~h}$ at room temperature, germinated at $25{ }^{\circ} \mathrm{C}$, and sown in sterile quartz sand soaked in Hoagland nutrient solution. Once the faba bean seedlings had grown 4-6 leaves, they were transplanted into $2 \mathrm{~L}$ containers containing various cinnamic acid concentrations. Treatments included 0 (control), 50, 100, and $200 \mathrm{mg} \cdot \mathrm{L}^{-1}$ of cinnamic acid. There were three replications of these treatments, resulting in 36 plants ( 3 replicate pots $\times 3$ seedlings $\times 4$ concentrations). The controls received Hoagland nutrient solution instead of cinnamic acid treatment, and the experiments were conducted under $24 \mathrm{~h}$ pump ventilation. After 2 days, the FOF spore suspension $\left(1 \times 10^{6} \mathrm{cfu} \cdot \mathrm{mL}^{-1}\right)$ was added to the nutrient solution.

\subsection{Determination of Faba Bean Growth Indices}

The faba beans were sampled at the branching stage. The number of leaves per plant, maximum leaf length and width, height, main root length, shoot dry weight, and root dry weight were measured.

\subsection{Measurement of the Incidence of Fusarium Wilt}

There were three replicates for four treatments, resulting in 72 plants ( 3 replicate pots $\times 6$ seedlings $\times 4$ concentrations) at the branching stage. Following the survey, the incidence of fusarium wilt and the disease index were calculated. The degree of disease was divided into 5 levels: 0 corresponding to no infection; 1 corresponding to initial symptoms of fusarium wilt, with the base of the stem or root (except the main root) being slightly discolored; 2 corresponding to the base of the stem or the root having lesions, though not being contiguous; 3 corresponding to 1/3-1/2 of the stem base or root showing lesions, discoloration, or wilt, and lateral roots being significantly reduced; 4 corresponding to the base of the stem being surrounded by lesions or most of the roots being discolored and wilted; and 5 corresponding to plants having died or totally wilted. The incidence of fusarium wilt and the disease index were calculated, using the following formulas:

$$
\begin{gathered}
\text { Incidence }=\frac{\text { Number of diseased plants }}{\text { total number of plants investigate }} \times 100 \% \\
\text { Disease index }=\frac{\sum(\text { Number of diseased plants at each level } \times \text { level })}{2 a \text { The highest level } \times \text { total number of plants investigated }} \times 100
\end{gathered}
$$

\subsection{Determination of Antioxidant Enzymes and Membrane Lipid Peroxidation}

Fresh root samples were used to determine peroxidase (POD), catalase (CAT), and malondialdehyde (MDA) activities, according to the method of Li [51].

POD activity was measured by the guaiacol method. A $1.0 \mathrm{~g}$ sample was ground into a homogenate with an appropriate amount of phosphate buffer. The homogenate was centrifuged at $3000 \mathrm{rpm}$ for $10 \mathrm{~min}$ and the supernatant was transferred to a $25 \mathrm{~mL}$ volumetric flask. We added $2.9 \mathrm{~mL}$ of $0.05 \mathrm{M}$ phosphate buffer, $1.0 \mathrm{~mL}$ of $2 \% \mathrm{H}_{2} \mathrm{O}_{2}, 1.0 \mathrm{~mL}$ of $0.05 \mathrm{M}$ guaiacol, and $0.1 \mathrm{~mL}$ of enzyme solution, and the solution was held in a $34{ }^{\circ} \mathrm{C}$ water bath for $3 \mathrm{~min}$, and then was rapidly diluted once. The absorbance at $470 \mathrm{~nm}$ was recorded at $1 \mathrm{~min}$ intervals for $5 \mathrm{~min}$.

CAT activity was assayed by potassium permanganate titration. A $1 \mathrm{~g}$ aliquot of the material and a small amount of phosphate buffer $(\mathrm{pH} 7.8)$ were ground into a homogenate, transferred to a 25 $\mathrm{mL}$ volumetric flask, and centrifuged at $4000 \mathrm{rpm}$ for $15 \mathrm{~min}$. A $2.5 \mathrm{~mL}$ aliquot of the supernatant was added to a measuring flask, and $2.5 \mathrm{~mL}$ of $0.1 \mathrm{M} \mathrm{H}_{2} \mathrm{O}_{2}$ was added. After $10 \mathrm{~min}$ of incubation in a constant-temperature water bath at $30^{\circ} \mathrm{C}, 2.5 \mathrm{~mL}$ of $10 \% \mathrm{H}_{2} \mathrm{SO}_{4}$ was immediately added. The solution was then titrated with a $0.1 \mathrm{M} \mathrm{KMnO}_{4}$ standard solution until a pink colour appeared. Enzyme activity was expressed in milligrams of $\mathrm{H}_{2} \mathrm{O}_{2}$ decomposed per gram of sample in $1 \mathrm{~min}$.

A $0.5 \mathrm{~g}$ portion of a plant sample was added to $5 \mathrm{~mL}$ of $5 \%$ TCA, and the homogenate was centrifuged at $3000 \mathrm{rpm}$ for $10 \mathrm{~min}$ after grinding. After mixing $2 \mathrm{~mL}$ of the supernatant and $2 \mathrm{~mL}$ of 
$0.67 \% \mathrm{TBA}$, the mixture was boiled in a water bath at $100{ }^{\circ} \mathrm{C}$ for $30 \mathrm{~min}$, and then centrifuged once again after cooling. Absorbance values at 450, 532, and $600 \mathrm{~nm}$ were measured, after which the MDA content was calculated.

\subsection{Determination of Pathogenesis-Related Protein activities}

We measured chitinase activity using a chitinase kit purchased from Nanjing Jiancheng Bioengineering Institute, and 1 unit of chitinase activity was defined as the amount of chitin that decomposed per gram of tissue per hour to produce $1 \mathrm{mg}$ of $\mathrm{N}$-acetyl-D-(+)-glucosamine. $\beta$-1,3-glucanase activity was measured using a $\beta-1,3$-glucanase kit purchased from Beijing Soleil Technology Co., Ltd. (Beijing, China); 1 unit of $\beta$-1,3-glucan enzyme activity was defined as $1 \mathrm{mg}$ of reducing sugar produced per gram of tissue per hour.

\subsection{Extraction and Quantification of Mycotoxin}

FOF was grown in Richard's medium [52], containing $10 \mathrm{~g}$ of $\mathrm{KNO}_{3}, 0.02 \mathrm{~g}$ of $\mathrm{FeSO}_{4}, 5 \mathrm{~g}$ of $\mathrm{KH}_{2} \mathrm{PO}_{4}, 2.5 \mathrm{~g}$ of $\mathrm{MgSO}_{4}, 34 \mathrm{~g}$ of glucose, and $1000 \mathrm{~mL}$ of distilled water to produce mycotoxin. The strain was transferred to a PDA plate medium and cultured at $28^{\circ} \mathrm{C}$ for 7 days. The diameter of the strain flake was $9 \mathrm{~mm}$. The flakes were transferred to $250 \mathrm{~mL}$ Erlenmeyer flasks with $125 \mathrm{~mL}$ of culture medium, and eight plates were placed in a shaker for 15 days at $28{ }^{\circ} \mathrm{C}$ with rotations at $180 \mathrm{rpm}$. The culture medium was centrifuged at $5000 \mathrm{rpm}$ for $10 \mathrm{~min}$, and the supernatant was filtered using a $0.45 \mu \mathrm{m}$ filter to remove mycelia and spores, after which the supernatant was collected and autoclaved to obtain the crude FOF toxin solution.

An equal volume of ethyl acetate was added to the crude toxin, shaken for $2 \mathrm{~min}$, and precipitated for $30 \mathrm{~min}$ to estimate mycotoxin production. The organic phase was collected and centrifuged at $4000 \mathrm{rpm}$ for $10 \mathrm{~min}$. The supernatant was dried at $40^{\circ} \mathrm{C}$, and the entire dried product was dissolved in $5 \mathrm{~mL}$ of ethyl acetate. Absorbance was determined at a wavelength of $269 \mathrm{~nm}$.

\subsection{Measurement of Pathogenesis-Related Hydrolytic Enzyme Activities}

The protease-producing culture medium contained $1 \%$ of inducing substrate (pectin and cellulose), $0.2 \mathrm{~g}$ of $\mathrm{MgSO}_{4} \cdot 7 \mathrm{H}_{2} \mathrm{O}, 0.4 \mathrm{~g}$ of $\mathrm{KH}_{2} \mathrm{PO}_{4}, 0.2 \mathrm{~g}$ of $\mathrm{KCl}, 1 \mathrm{~g}$ of $\mathrm{NH}_{4} \mathrm{NO}_{3}, 0.01 \mathrm{~g}$ of $\mathrm{FeSO}_{4}, 0.01 \mathrm{~g}$ of $\mathrm{ZnSO}_{4}$, and $0.01 \mathrm{~g}$ of $\mathrm{MnSO}_{4}$ in distilled water, being a total volume of $1 \mathrm{~L} \mathrm{[53].} \mathrm{We} \mathrm{added} 25 \mathrm{~mL}$ of the enzyme-producing medium to $100 \mathrm{~mL}$ Erlenmeyer flasks, and FOF flasks (diameter: $9 \mathrm{~mm}$ ) were cultured for 7 days at $28{ }^{\circ} \mathrm{C}$ and $200 \mathrm{rpm}$. The culture medium was collected and centrifuged at $4000 \mathrm{rpm}$ for $10 \mathrm{~min}$, and the supernatant was filtered through a $0.45 \mu \mathrm{m}$ filter. The filtrate was the crude enzyme solution, which was stored at $4{ }^{\circ} \mathrm{C}$ until measurements were conducted.

We prepared 3,5-dinitrosalicylic acid (DNS) reagents according to a previously described method [54]. We added $3.15 \mathrm{~g}$ of DNS to $500 \mathrm{~mL}$ of water while stirring for $5 \mathrm{~s}$ and heated the solution to $45^{\circ} \mathrm{C}$. $100 \mathrm{~mL}$ of $0.2 \mathrm{~g} \cdot \mathrm{mL}^{-1}$ sodium hydroxide solution was then gradually added while stirring until the solution was transparent. The solution temperature did not exceed $48{ }^{\circ} \mathrm{C}$ during the addition of the sodium hydroxide. We added $91.0 \mathrm{~g}$ of sodium nitrate potassium tartrate, $2.5 \mathrm{~g}$ of phenol, and $2.5 \mathrm{~g}$ of anhydrous sodium sulphite, and placed the solution in a water bath to heat it to $45^{\circ} \mathrm{C}$ while adding $300 \mathrm{~mL}$ of water with constant stirring until the material was completely dissolved. Finally, the solution was cooled to room temperature and distilled water was added to a final volume of $1 \mathrm{~L}$. The solution was stored at room temperature in the dark for 7 days before use. A unit of enzyme activity was defined as $1 \mu \mathrm{mol}$ of galacturonic acid produced by pectinase hydrolysis per min, or the amount of enzyme required to produce $1 \mu \mathrm{mol}$ of glucose per min.

\subsection{Statistical Analysis}

All data were analyzed using Microsoft Excel 2010 software (Microsoft Corp., Redmond, WA, USA) and SPSS software (ver. 20.0; SPSS Inc., Chicago, IL, USA). The least significant difference test was used to determine differences between the treatments, at a significance level of $p<0.05$. 


\section{Conclusions}

Cinnamic acid significantly stimulated FOF, which produced fusaric acid and hydrolase, inhibited faba bean seedling growth, and stimulated membrane lipid peroxidation in faba beans' roots, destroying the host defence system against the pathogen. This process may explain why, in this study, plant morbidity and disease indices were found to increase, compared with the control.

Author Contributions: Conceptualization, Q.Z. and L.C.; Methodology, L.C.; Software, Q.Z.; Validation, L.C., K.D. and Y.D.; Formal Analysis, Q.Z.; Investigation, L.C.; Resources, J.X.; Data Curation, Q.Z.; Writing-Original Draft Preparation, Q.Z.; Writing-Review \& Editing, Q.Z.; Supervision, K.D.; Project Administration, Y.D.; Funding Acquisition, Y.D.

Funding: We gratefully acknowledge the National Nature Science Foundation of China $(31860596,31560586$, 31360507) for funding this project.

Conflicts of Interest: The authors declare no conflict of interest, and the funders had no role in the study.

\section{References}

1. Stoddard, F.L.; Nicholas, A.; Rubiales, D.; Thomas, J.; Villegas-Fernández, A.M. Integrated pest, disease and weed management in faba bean. Field Crops Res. 2010, 115, 308-318. [CrossRef]

2. Jensen, E.S.; Peoples, M.; Hauggaard-Nielsen, H. Faba bean in cropping systems. Field Crops Res. 2010, 115, 203-216. [CrossRef]

3. Zhen, W.C. Study on the Mechanism and Control of Replant Disease on Strawberry (Fragaria ananassa Duch). Master's Thesis, Agricultural University of Hebei Province, Baoding, China, 2003.

4. Wu, X.H.; Lu, Z.J.; Wang, P.P.; Yang, L.Y. Current advances in integrated management of watermelon Fusarium wilt. Plant Prot. 2011, 37, 27-32.

5. Zhang, F.G.; Zhu, Z.; Yang, X.M.; Ran, W.; Shen, Q.R. Trichoderma harzianum T-E5 significantly affects cucumber root exudates and fungal community in the cucumber rhizosphere. Appl. Soil Ecol. 2013, 72, 41-48. [CrossRef]

6. Ye, Y. Chinese Faba Beans, 1st ed.; China Agriculture Press: Beijing, China, 2003; pp. 450-451, ISBN 7-109-08243-1.

7. Zhou, X.G.; Wu, F.Z. P-Coumaric Acid Influenced cucumber rhizosphere Soil microbial communities and the growth of Fusarium oxysporum f. sp. cucumerinum owen. PLoS ONE 2012, 7, e48288. [CrossRef]

8. Chen, S.L.; Zhou, B.L.; Lin, S.S.; Xia, L.; Ye, X.L. Accumulation of cinnamic acid and vanillin in eggplant root exudates and the relationship with continuous cropping obstacle. Afr. J. Biotechnol. 2011, 10, 2659-2665.

9. Hao, W.Y.; Ran, W.; Shen, Q.R.; Ren, L.X. Effects of root exudates from watermelon, rice plants and phenolic acids on Fusarium oxysporum f. sp. niveum. Sci. Agric. Sin. 2010, 43, 2443-2452.

10. Li, Z.F.; Yang, Y.Q.; Xie, D.F.; Zhu, L.F.; Zhang, Z.G.; Lin, W.X. Identification of autotoxic compounds in fibrous roots of rehmannia (RehmannHia glutinosa Libosch.). PLoS ONE 2012, 7, e28806. [CrossRef]

11. Wu, Z.J.; Yang, L.; Wang, R.Y.; Zhang, Y.B.; Shang, Q.H.; Wang, L.; Ren, Q.; Xie, Z.K. In vitro study of the growth, development and pathogenicity responses of Fusarium oxysporum to phthalic acid, an autotoxin from Lanzhou lily. World J. Microbiol. Biotechnol. 2015, 31, 1227-1234. [CrossRef] [PubMed]

12. Ye, S.F. Research on Promotive Effects of Fusarium Wilt in Cucumis sativus by Cinnamic Acid, an Autotoxin in Root Exudates of Cucumis saitvus L., and Mitigation Mechanism by Grafting and Cinnamic Acid-Degrading Microbial Strains. Master's Thesis, Zhejiang University, Hangzhou, China, 2004.

13. Asaduzzaman, M.; Asao, T. Autotoxicity in beans and their allelochemicals. Sci. Hortic. 2012, 134, 26-31. [CrossRef]

14. Hu, Y.S.; Wu, K.; Li, C.X.; Sun, F.L.; Jia, X.C. Effects of phenolic compounds on the growth of cucumis sativus seedlings and Fusarium oxysporum hypha. Chin. J. Ecol. 2007, 26, 1738-1742.

15. Wang, R.H.; Zhou, B.L.; Zhang, Q.F.; Lian, H.; Fu, Y.W. Effects of vanillin and cinnamic acid in root exudates of eggplants on Verticillium dahliae etc. Acta Ecol. Sin. 2006, 26, 3152-3155.

16. Yang, J.X.; Gao, W.W. Effects of Phenolic Allelochemicals on the pathogen of Panax quiquefolium L. Chin. Agric. Sci. Bull. 2009, 25, 207-211.

17. Dong, Y.; Dong, K.; Yang, Z.X.; Zheng, Y.; Tang, L. Microbial and physiological mechanisms for alleviating Fusarium wilt of faba bean in intercropping system. Chin. J. Appl. Ecol. 2016, 27, 1010-1020. 
18. Song, L.; Pan, K.W.; Wang, J.C.; Ma, Y.H. Effects of phenolic acids on seed germination and seedling antioxidant enzyme activity of alfalfa. Acta Ecol. Sin. 2006, 26, 3393-3403.

19. Li, X.; Zhou, B.L.; Chen, S.L.; Lin, S.S. Effects of the auto toxic substance in eggplant on pepper seed germination and Fusarium oxysporum f sp. Acta Ecol. Sin. 2009, 29, 960-965.

20. Tian, G.L.; Bi, Y.M.; Sun, Z.J.; Zhang, L.S. Phenolic acids in the plow layer soil of strawberry fields and their effects on the occurence of strawberry anthracnose. Eur. J. Plant Pathol. 2015, 143, 581-594. [CrossRef]

21. Qi, Y.Z.; Su, Y.; Wang, N.; Zhen, W.C. Observation on histological structure of strawberry roots after inoculating Fusarium oxysporum f. sp. fragariae under 4-hydroxybenzoic acid stress. Acta Hortic. Sin. 2015, 42, 1909-1918.

22. Wang, Q.; Li, X.L. Effects of benzoic and cinnamic acids on watermelon seedling growth and fusarium wilt occurrence. J. China Agric. Univ. 2003, 8, 83-86. [CrossRef]

23. Guo, H.W.; Guo, S.R.; Liu, L.; Sun, J.; Huang, B.J. Effects of continuous cropping on physical and chemical properties of soil, physiological resistance and ion absorption of pepper. Soils 2012, 44, 1041-1047.

24. Wang, R.H.; Qu, G.F.; Zhang, Q.F.; Li, D.D.; Liu, F.; Qin, Z.H. Effect of vanillin on seedling growth and physiological characteristics of tomato. North. Hortic. 2014, 5, 12-14.

25. Wu, F.Z. Studies on Physiological and Biochemical Mechanism of Exogenous Phenolic Acid on Cucumber's Auto-Toxic Effect. Master's Thesis, Northeast Agricultural University, Harbin, China, 2002.

26. Qi, Y.Z. Study on Synergistic Effect of Root Allelochemical and Pathogen in the Replant Disease of Strawberry. Master's Thesis, Agricultural University of Hebei Province, Baoding, China, 2008.

27. Wang, Y.F.; Pan, F.B.; Zhan, X.; Wang, G.S.; Zhang, G.D.; Hu, Y.L.; Chen, X.S.; Mao, Z.Q. Effects of five kinds of phenolic acid on the function of mitochondria and antioxidant systems in roots of Malus hupehensis Rehd seedlings. Acta Ecol. Sin. 2015, 35, 6566-6573.

28. Jiao, X.L.; Bi, X.B.; Gao, W.W. Allelopathic effect of p-coumaric acid on American ginseng and its physiological mechanism. Acta Ecol. Sin. 2015, 35, 3006-3013.

29. Xu, W.H.; Liu, D.; Wu, F.Z.; Liu, S.W. Root exudates of wheat are involved in suppression of Fusarium wilt in watermelon in watermelon-wheat companion cropping. Eur. J. Plant Pathol. 2015, 141, 209-216. [CrossRef]

30. Zuo, Y.H.; Kang, Z.S.; Yang, C.P.; Rui, H.Y.; Lou, S.B.; Liu, X.R. Relationship between activities of 13-1.3-glacanase and chitinase and resistance to phytophthora root rot in soybean. Acta Phytopathol. Sin. 2009, 39, 600-607.

31. Kang, Y.Y.; Zhou, X.M.; Yang, X.; Lin, J. Effect of p-hydroxybenzoic acid on induced resistance of flowering Chinese cabbage to anthracnose and the associated plant physiological characters. Acta Phytopathol. Sin. 2014, 44, 393-404.

32. Ren, L.X. Physiological Mechanisms for Suppressing Watermelon Wilt Disease by Intercropped with Aerobic Rice. Master's Thesis, Nanjing Agricultural University, Nanjing, China, 2012.

33. Ye, S.F.; Yu, J.Q.; Peng, Y.H.; Zheng, J.H.; Zou, L.Y. Incidence of fusarium wilt in Cucumis sativus L. is promoted by cinnamic acid, an autotoxin root exudate. Plant Soil 2004, 263, 143-150. [CrossRef]

34. Wu, H.S.; Liu, D.Y.; Ling, N.; Bao, W.; Ying, R.R.; Shen, Q.R. Influence of root exudates of watermelon on Fusarium oxysporum f. sp. niveum. Soil Biol. Biochem. 2009, 73, 1150-1156.

35. Zhen, W.C.; Wang, X.Y.; Kong, J.Y.; Cao, K.Q. Determination of phenolic acids in root exudates and decomposing products of strawberry and their allelopathy. J. Agric. Univ. Hebei 2004, 27, 74-78.

36. Chen, S.L.; Zhou, B.L.; Wang, R.H.; Fu, Y.W. Regulation effect of grafting on cinnamic acid and vanillin in eggplant root exudates. Chin. J. Appl. Ecol. 2008, 19, 2394-2399.

37. Hao, W.Y.; Ren, L.X.; Ran, W.; Shen, Q.R. Allelopathic effects of root exudates from watermelon and rice plants on Fusarium oxysporum f. sp. niveum. Plant Soil 2010, 336, 485-497. [CrossRef]

38. Qi, Y.Z.; Jin, J.J.; Chang, N.; Zhang, X.J.; Yin, B.Z.; Zhen, W.C. Improvement effect of 4-hydroxybenzoic acid on occurrence of wilt disease of strawberry. China Plant Prot. 2016, 9, 5-10.

39. Johnson, R.D.; Johnson, L.; Itoh, Y.; Kodama, M.; Otani, H.; Kohmoto, K. Cloning and characterization of a cyclic peptide synthetase gene from Alternaria alternata apple pathotype whose product is involved in AM-toxin synthesis and pathogenicity. Mol. Plant-Microbe Interact. 2000, 13, 742-753. [CrossRef] [PubMed]

40. Masumake, A.; Tamaka, A.; Tsuge, T.; Peever, T.L.; Timmer, L.W.; Yamamoto, M.; Yamamoto, H.; Akimitsu, K. Distribution and characterization of AKT homologs in the tangerine pathotype of Alternaria alternata. Phyotopathology 2000, 90, 762-768. [CrossRef] [PubMed] 
41. Masumake, A.; Ohtani, K.; Peever, T.L.; Timmer, L.W.; Tsuge, T.; Yamamoto, M.; Yamamoto, H.; Akimitsu, K. An Isolate of Alternaria alternate that is pathogenic to both tangerines and rough lemon and produces two host-selective Toxins, ACT-and ACR-toxins. Phyotopathology 2005, 95, 241-247. [CrossRef] [PubMed]

42. Geimba, M.P.; Corbellini, V.A.; Scroferneker, M.L. Chemical and immunological differentiation of exoantigens from four Bipolaris sorokiniara strains. Process Biochem. 2005, 40, 2051-2057.

43. Kosiak, E.B.; Jensen, A.H.; Rundberget, T.; Torp, M.T.G.M. Morphological, chemical and molecular differentiation of Fusarium equiseti isolated from Norwegian cereals. Int. J. Food Microbiol. 2005, 99, 195-206. [CrossRef] [PubMed]

44. Ghédira-Chékir, L.; Maaroufi, K.; Zakhama, A.; Ellouz, F.; Dhouib, S.; Creppy, E.E.; Bacha, H. Induction of a SOS repaire system in lysogenic bacteria by zearalenone and its derivatives by vitamin E. Chem.-Biol. Interact. 1998, 113, 15-25. [CrossRef]

45. Minervini, F.; Giannoccaro, A.; Cavallini, A.; Visconti, A. Investigations on cellular proliferation induced by zearalenone and its derivatives in relation to the estrogenic parameters. Toxicol. Lett. 2005, 159, 272-283. [CrossRef] [PubMed]

46. Chen, B.; Wang, K.Y.; Dong, G.Q.; Yuan, K.P.; Lin, K.J. The correlations in the pathogenicity to the enzymes' activities of Thanatephorus Cucumeris causing rice sheath blight disease. Acta Agric. Zhejiangensis 1992, 4, 8-14.

47. Vidhyasekaran, P. Fungal Pathogenesis in Plants and Crops, 2nd ed.; Haworth Food \& Agricultural Products Press: New York, NY, USA, 1997; p. 568, ISBN 0-8247-0039-2.

48. Zhou, X.G.; Yu, G.B.; Wu, F.Z. Effects of intercropping cucumber with onion or garlic on soil enzyme activities, microbial communities and cucumber yield. Eur. J. Soil Biol. 2011, 47, 279-287. [CrossRef]

49. Broz, A.K.; Broeckling, C.D.; De-la-Peña, C.; Lewis, M.R.; Greene, E.; Callaway, R.M.; Sumne, L.W.; Vivanco, J.M. Plant neighbor identity influences plant biochemistry and physiology related to defense. BMC Plant Biol. 2010, 10, 115. [CrossRef] [PubMed]

50. Abdel-Monaim, M.F.; Abo-Elyousr, K.A.M. Effect of preceding and intercropping crops on suppression of lentil damping-off and root rot disease in New Valley e Egypt. Crop Prot. 2012, 32, 41-46. [CrossRef]

51. Li, H.S. Principles and Techniques of Plant Physiological Biochemical Experiment, 1st ed.; Higher Education Press: Beijing, China, 2000; pp. 164-165, ISBN 7-04-008076-1.

52. Gaumann, E. Fusaric acid as a wilt toxin. Phytopathology 1957, 47, 342-357.

53. Di Pietro, A.; Roncero, M.I.G. Endopolygalacturonase from Fusarium oxysporum f. sp. lycopersici: Purification, characterization, and production during infection of tomato plants. Phytopathology 1996, 86, 1324-1330.

54. Cao, C.L.; Cui, B.K.; Qin, W.M. Activity changes of several extracellular enzymes in liquid culture of Phellinus mori. Inst. Microbiol. 2011, 30, 275-280. 